\title{
Transcending boundaries: options and prospects for interfacing living library traditions and academic library systems
}

\begin{abstract}
This paper has focused on knowledge production in Ghana with the view to understanding how traditional and academic systems can inspire each other in mutually beneficial ways. It sought to evaluate the gaps and opportunities to determine possible ways to integrate the knowledge management mechanisms of indigenous living libraries and academic library systems. "With a descriptive case study design, this study employed a blend of qualitative techniques involving in-depth interviews, focus group discussions, storytelling, phased assertion, historical profiling and acoustic appreciation to elicit responses from a total of 32 senior members from three public universities, 40 baansi and four (4) Dagbon scholars. The data were analyzed using Thematic/content analysis. The study confirmed the generally held assertion of the evident differences in the two knowledge systems albeit several often-overlooked similarities existed too. Indigenous Knowledge and Western science have something to offer although they both have their weaknesses. The study concludes that the appreciation of the two traditions will be helpful for gaining deeper understanding for promoting synergies toward reconstructing librarianship in Africa. The study also recommends a model for creating synergy between living and academic libraries with an emphasis on learning together and mutual respect for the co-evolution of their systems.
\end{abstract}

Keywords: Baansi, Academic Libraries, Preservation of Cultural Heritage Indigenous Knowledge
Volume 3 Issue 4 - 2018

\author{
Florence Dedzoe Dzokotoe Plockey \\ Senior Assistant Librarian, University for Development Studies, \\ Ghana
}

Correspondence: Florence Dedzoe Dzokotoe Plockey, Senior Assistant Librarian, University for Development Studies, Ghana, Email fplockey@yahoo.com

Received: April 19,2018| Published: July 10, 2018

\section{Introduction}

Traditionally, ethnic communities have preserved and transmitted knowledge generated from their beliefs, institutions and customs from one generation to another. With the introduction of Western systems, such communities have also participated in the formalized knowledge system preserved and transmitted through formal institutions of learning such as schools, colleges and universities. This paper explores possibilities and options for the fostering of the co-evolution of the two knowledge production systems: the living libraries (baansi) of Dagbon and the academic libraries in Ghana. The baansi is a collective name for musicians in Dagbon, Ghana. They are court musicians who involve themselves in praise singing. They are also holders of cultural knowledge, custom and history of Dagbon. Salifu ${ }^{1}$ re-echos Oppong ${ }^{2}$ by emphasizing that the living librarians act as family historians, royal advisors, cultural specialists and entertainers and in the view of Chista and Abdullahi, ${ }^{3}$ they are "walking or living libraries." Academic Libraries are libraries of tertiary schools. The paper is divided into three sections. This first section examines the divergences between the Living Libraries (baansi) and the Academic Libraries (AL) whiles the second and third delineates the commonalities between the Living Libraries and Academic Libraries as points of convergence. It also provides a synthesis of the knowledge management of the two systems: the living libraries (baansi) of Dagbon and the academic libraries in Ghana. The study also recommends a model for creating synergybetween baansi and academic libraries with emphasis on learning together and mutual respect for co-evolution of their systems.

\section{Methodology}

A descriptive case study design was used in this qualitative study. Data was collected from multiple sites (Universities and local communities) purposively selected to ensure that the respondents in the study were directly involved in the knowledge creation and management in either settings.

\section{Population and sampling}

Thus, all seniors' members of ALs in 3 public university; namely University of Ghana (UG) (Legon), University of Cape Coast (UCC) and University for Development Studies (UDS) were eligible to participate in this study. These ALs were purposively selected as the principal public universities for a geographically representative spread of ALs in the country (Southern, Middle and Northern zones respectively). For the sake of anonymity, these universities were randomly coded A, B, C. In the end, a total of 32 senior members from three (3) public university libraries and 40 baansi were reached through snow ball technique. Also, four (4) Dagbon ${ }^{1}$ scholars were also purposively identified and added to the sample.

\section{Data collection methods}

As the purpose of this paper, is to evaluate potential gaps and opportunities in creating synergies in both $\mathrm{IK}$ and $\mathrm{AL}$ from the perspective of the key actors in other to identify future integration,

${ }^{1}$ Land of the Dagbamba. The Dagbamba are also called Dagomba. Their language is Dagbanli, wrongly called Dagbanini 
the researcher employed a combination of the in-depth data collection techniques including in-depth interviews, focus group discussions, storytelling, phased assertion, historical profiling and acoustic appreciation to elicit responses from study participants. 45 numbers of in-depth interviews were scheduled for both $\mathrm{AL}$ and baansi using a validated interview guide. According to Collings, ${ }^{4}$ the best technique of interview is the probing method is baiting"5 or "phased assertion". 6 The basic principle of this method is that the interrogator behave as if she or he has some idea about the topic understudy, this inspired the informants to give more information. This method was very helpful for the baansi to open up since the assertion of prior knowledge led to acquisition of a bit more knowledge, which, in turn, led to more detailed knowledge, until a more complete understanding of a particular domain was achieved. Before the study the researcher got some prior knowledge about the baansi from people and from books.

To further deepen the analysis, the researcher engaged some selected baansi in Focus Group Discussions (FGD). In all, four focus group sessions were held, which included:

a. the chief and elders of Burlana's Naa palace (a total of 10 participants)

b. baansi from Yendi palace (a total of 8 participants)

c. baansi from Dakpema Palace in Tamale (a total of 5 participants)

d. baansi from Gbalkurani community in Tamale (a total of 7 participants - mainly youth).

The researcher observed a number of major events. The purpose of the observations was to see at first-hand how the information collected in the FGDs and interviews were actually enacted within the culture as well as to corroborate the data that were previously captured in the in-depth interviews and the FGDs. It also offered the opportunity to ask further questions to clarify and/or learn new concepts that hitherto were not mentioned in previous engagements. The researcher was also told stories about their experiences as Baansi from childhood through their youth to adulthood.

\section{Data analysis}

Each interview session was audio-taped and transcribed immediately after the interviews were completed by trained field assistants and compared with the field notes. A thematic content analysis approach was used to report the findings in this study. Key phrases with similar meanings were coded into themes and subthemes using descriptive narratives to reflect the collective world views of all the stakeholders. Main and sub-themes were generated from the data collected by using coding which involved categorizing ideas and concepts from the stories and interviews and using constant comparative analysis of the issues and emerging issues trends. All data were analyzed manually and quotations from respondents are presented in italics.

\section{Findings and analysis}

\section{Divergences between the living libraries of dagbon and the academic libraries of ghana}

Indigenous knowledge is different from Western or conventional knowledge (CK) in many ways. As Nyamnjoh ${ }^{7}$ has intimated, indigenous knowledge creates room for many interrogation and for magical interpretation where there is no obvious reality. The basis of such IK will be unacceptable in conventional knowledge. This study has been interested in examining the differences between the IK-based Living Libraries of Dagbon (baansi) and the CK-based Academic Libraries of Ghana. Some of the main differences found are examined below.

\section{Structure}

The baansi, traditional historians and knowledge producers and holders of Dagbon, who are often referred to as 'walking libraries' (living libraries) and academic libraries are both storehouse of knowledge. Whereas the latter is a building containing prints and electronic materials, the former takes the form of human beings who commit the knowledge of their community into memory. During the community-based interactions I had with various baansi the following was revealed: We have committed the chief in tradition into their memory. And this oral tradition has been transmitted more than 700 year ago; they know you more than you know yourself. (baansi, Interview, 12/4/2013). According to Heng ${ }^{8}$ a library is influenced by its environment and so it defines itself through the collection of knowledge for education, research and politics. Therefore the library is not a mere collection of books and other reading materials, it also include other forms of storing information which if not consulted may not provide a holistic picture of the history of a people.

\section{Qualification}

The baansi as professionals acquire their status through hereditary of tradition encumbered with hands-on training while the qualification to become an academic librarian is solely by training, an academic proviso. Becoming a drummer in Dagbon, for instance is not by choice but a social obligation. This means that the baansi do not have the luxury of choice and their talents, they must stay in the practice as a family tradition. The community-level interactions show the baansi had fathers who were baansi. One of the informants said baansi is: an inherited profession (baansi, Interview, July, 2015). On the other hand, academic librarians are highly educated and technology savvy professionals with many holding postgraduate degrees. Currently, the University of Ghana, Legon is the only institution in Ghana that trains librarians. This training culminates in awards ranging from Diploma through Bachelors and Masters to Doctorate Degrees. Unlike the baansi, academic librarianship is not hereditary or mandatory but by choice. People choose to become academic librarians through either self-interest or recommendations. However, regardless of the differences in the mode and means of qualification of the baansi of academic librarians, they are both knowledgeable in their chosen profession. As such, they can work together with mutual respect.

\section{Boundaries}

The knowledge realm of the baansi is boundless while academic libraries are confined to demarcated spaces in their parent institutions. Academic libraries exist in academic institutions for academic work while the baansi exist in society and for social living. For instance, academic libraries provide information to only those in the academic institution and this is confirmed by Shannon and Bossaller, when he stated that librarians work within boundaries. However, the baansi provide information to the people of Dagbon and also to those who may be interested. In other words, the baansi serve diverse manner of people of varying persuasions, the lettered and unlettered.However, the academic libraries serve only the lettered class thereby leaving those who are unlettered. Again, the baansi are able to perform 
everywhere and every time. They are mobile, unlike the academic libraries which are confined to the academic institutions. That is to say the baansi are able to bring their services to the doorsteps of their clients. That is why they are also referred to as walking librarians or moving encyclopedias. According to one of the respondents, we went to social functions and market on market days to perform (baansi, Interview, 7 June, 2013). Despite these differences discussed, the baansi and the academic libraries can still work together.

\section{Mandate}

The baansi serve as the "watch dog" of the society as a whole. However, academic libraries are purely established to serve the interest of the academic institutions such as providing access to information and all the respondents confirmed it. It is the duty of the baansi to look out for those who behave in ways outside of accepted social norms and through the use of talk, music and proverbs to remind such persons of what constitutes proper and improper behavior and/or the consequences of improper behaviour by referring to the experiences of some other persons in the past who had behaved in a similar way. A respondent had this to say; Baansiare the "conscience of the society." They put the people right when they are going wrong. On the contrary, academic libraries are information providers and they do not really care about people's behaviors in the society. As such academic libraries do not act as "watch dogs "as in the case of the baansi.

\section{Documentations/collections}

The baansi deal with unrecorded and unpublished documents whereas academic libraries are concerned generally with books and published documents. The baansi generate the knowledge themselves and they store it orally and through drum beat, song and gesture. A respondent indicated that: learning is tradition and a way of life. As you practice and interact with society you acquire knowledge. Academic libraries focus on print collections. This is supported by Lor $^{9}$ assertion that librarians are generally more comfortable dealing with publications than with unrecorded and unpublished knowledge and library theories and systems are geared mainly to dealing with published documents. On the other hand, unrecorded or unpublished documents are not available in print.

\section{Methods of acquisition of materials}

The methods of acquiring materials for the academic libraries and the baansi are different. While knowledge acquisition of the baansi is socially constructed, that of the academic library is mechanically constructed. According to dictionary.com social construct is a social mechanism, phenomenon, or category created and developed by society; a perception of an individual, group, or idea that is 'constructed' through cultural or social practice. This makes the knowledge subjective, communal and holistic. For example, the living librarians of Dagbon (baansi) acquire their knowledge through oral transmission from one generation to the other. The study also revealed that the training is virtually practical. In order to acquire knowledge, a learner must directly and actively involve or socially participate in a community. This confirms Moahi ${ }^{10}$ assertion that the daily interaction in life and world is the most basic means of experiencing, teaching and learning.

On the contrary, a mechanical construct is similar to relativist perspectives where knowledge is created and not constructed. Knowledge is considered to be more precise and hence more reliable.
Compared to a social construct (as in living libraries), mechanical construct (as in academic libraries) is based on the scientific method of proof and validation, objectivity, Individualism; being able to see something for what it is without personal bias. Academic libraries acquire their materials through purchases, donations, gifts, legal deposits in some few cases, loans, and knowledge sharing. Gibbons et al. ${ }^{11}$ acknowledge that knowledge is science and knowledge producers are scientific but knowledge of the natural world is not confined to science.

\section{Storage of information/materials}

Storage is traditionally soft human media for the baansi while academic libraries store in hard and technological media. The baansi basically store most of their knowledge in the human memory. Thus, the baansi storage system is human dependent. Adeliberation with the baansi indicated that the Baansi were able to retain so much information in memory. In a focus group discussion, the group members were of the opinion that: the baansi preserve tradition; prevent adulteration of the people's culture; (Lunsi/Akairma/Goonjee, Focus group discussion/18/6/2013); they clarifiedthat practice made one perfect. A respondent admitted that they were given herbal charms or concoction to improve their memory. This is contrary to academic libraries where information/knowledge is mostly in text. According to Shannon and Bossaller, storage practices "raise issues of secrecy, memory, prestige, and knowledge" and provide insight into what a society values. Storage practices might manifest in a variety of ways. Shannon and Bossaller succinctly, put it as: Their expression of "truth" relates to the idea that what we know, or what we respect, is found in books - that there is a definite way of knowing that can be found "in the stacks" through the lens of positivism. While this is not inherently problematic, their education would be enriched by looking toward grandparents and others who are outside of the center of these institutionalized paths to knowledge. However, such inclusion forces librarians, as well as students, to rethink authority - to expand their conception of truth, to provide academic legitimacy to that wisdom of lived experience. The differences between the baansi and the academic libraries are summarized below in Table 1. The analyses so far clearly show that there are divergences between the two library systems: the living (baansi) and academic libraries. However, in spite of their differences, they have things in common. These commonalities of convergences are discussed in the next section.

\section{Convergences between the Living Libraries and Academic Libraries}

Mbembe (1997) argues that understanding the visible is hardly complete without investigating the invisible. We misunderstand the world if we consider the obverse and the reverse of the world as two opposite sides, with the former partaking of a 'being there' (real presence) and the latter as 'being elsewhere' or a 'non-being' (irremediable absence) or, worse, of the order of unreality. The obverse and its reverse are also linked by similarities which do not make them mere copies of each other, but which unite and at the same time distinguish themselves according to the 'principle of simultaneous multiplicities'. ${ }^{7}$ This means that no matter the differences, there are certain things that bind the two knowledge systems together. Thus, this section examines the similarities between academic libraries and the baansi as points of convergence which offer opportunities for cross learning and co-evolution. 
Table I The differences between the Baansi and the Academic Libraries

\begin{tabular}{|c|c|}
\hline Baansi & Academic Libraries \\
\hline \multicolumn{2}{|l|}{ Structure } \\
\hline Human being & Buildings \\
\hline \multicolumn{2}{|l|}{ Qualifications } \\
\hline Hereditary & Academic qualification \\
\hline Mandatory & By choice \\
\hline \multicolumn{2}{|l|}{ Boundaries } \\
\hline Boundless & Confined to Parent institutions \\
\hline \multicolumn{2}{|l|}{ Movable } \\
\hline \multicolumn{2}{|l|}{ Training } \\
\hline Lifelong & Time bound \\
\hline Starts from Childhood & Starts from Adulthood \\
\hline Method is holistic & Method is Reductionist \\
\hline \multicolumn{2}{|l|}{ Mandate } \\
\hline Watchdog of the society & $\begin{array}{l}\text { Support teaching, learning and } \\
\text { research }\end{array}$ \\
\hline \multicolumn{2}{|l|}{ Documentation } \\
\hline $\begin{array}{l}\text { Deals with unpublished and } \\
\text { unrecorded documents (oral, signs, } \\
\text { drums beats, sound, etc) }\end{array}$ & $\begin{array}{l}\text { Deals largely with published } \\
\text { documents }\end{array}$ \\
\hline \multicolumn{2}{|l|}{ Scope of knowledge } \\
\hline $\begin{array}{l}\text { Social, political and economic } \\
\text { history of Dagbon. }\end{array}$ & $\begin{array}{l}\text { From Archeology to Zoology } \\
\text { (A-Z)Depending on the mission } \\
\text { of the Library }\end{array}$ \\
\hline \multicolumn{2}{|l|}{ Storage } \\
\hline Soft and human media & Hard and technological media \\
\hline
\end{tabular}

\section{Knowledge producers}

As already intimated, the baansi, like academic libraries, are knowledge producers. The baansi according to this study, are holders of cultural wisdom and the socio-political history of the people of Dagbon. Similarly, the academic library is the site of knowledge. Universities are understood as knowledge producers responsible for fostering economic development. Every society has a dominant ideology, and most libraries necessarily reflect or manifest the ideology of the society they serve Atkinson. ${ }^{12}$ As academic libraries support the interest of the parent institution, knowledge produced in the library is geared toward supporting teaching, learning and research in the tertiary educational institutions. The story, music, drumming and the dance of the baansi are central to the knowledge production and dissemination process. Through their stories and teaching the baansi produce knowledge. An informant had this to say: but for them we would have forgotten who we are; but for them society will be tensed and explode; they are tradition bearers and but for them there would be no group identity. (baansi, Interview, 12/6/2015) According to Oppong, ${ }^{2}$ the people of Dagbon use socialisation agents such as dance, goonje and lunsi ceremonies, which include weddings, festivals, out doorings, funerals and enskinments as socialisation agents to produce knowledge. This is very important since generally in Africa and particularly in Ghana, the transmission of oral culture has been the anchor for sustaining, perpetuating and disseminating information; a means that helps to sustain the collective memory of society from generation to generation. ${ }^{3}$ This also applies to the role of academic libraries relating user education, information literacy, indexing, research and publication, which are processes used to produce knowledge. According to Alemna (1993), libraries need to be centres for knowledge production not just knowledge consumption. Knowledge production means the cluster of related activities in the institution such as a University that has to do with producing new knowledge. ${ }^{13}$ The various activities enumerated above are all related activities that support knowledge production in the academic libraries in Ghana.

\section{Gateway to Knowledge}

The study revealed that both the academic library and the baansi of Dagbon are gateways to knowledge. Libraries are gateways to knowledge and culture; libraries play a fundamental role in society. The resources and services they offer create opportunities for learning, supporting literacy and education, and helping shape the new ideas and perspectives that are central to a creative and innovative society. They also help ensure authentic records of knowledge created and accumulated by past generations are preserved and for use. In a world without libraries, it would be difficult to advance research and human knowledge or preserve the world's cumulative knowledge and heritage for future generations. ${ }^{14}$ Academic libraries are responsible for preserving and providing access to the scholarly records. For example, academic libraries, in cataloguing and classifying their materials, are able to provide access to countless information that would have been difficult to access by users. Below is a comment by one of the respondents: In my area of expertise (cataloguing), it is important to understand the whole library structure as much as possible. A lot of my work involves using judgment to connect resources in the best way possible so that patrons and library workers can find them. The collections that they hold over a period take on cultures on their own as genre. It is not surprising that cataloguing and classification are considered as "key" to unlock information in the library. Similarly, the baansi also act as holders of Dagbon histories. They keep the past of Dagbon in view and in memory. Through drumming, singing, and dancing the baansi provide access to information. This shows that both the baansi and the academic libraries hold knowledge and provide access to knowledge for their respective users.

\section{Knowledge expertise}

The baansi and the academic libraries are experts in their respective fields. Like academic librarians, the baansi exercise deep knowledge and skills in order to produce, store and share knowledge. Academic libraries are known in their professional knowledge to select, acquire, organize, store and disseminate information to support teaching and learning in the institution and also to provide information literacy to their users. According to Abdulsalami, Okezie and Agbo ${ }^{15}$ libraries also engage the services of librarians who are experts at finding and organizing information and at interpreting information needs. Similarly, the baansi are experts in their field. Below is the story of a drummer. When the researcher asked Yahaya Ziblim, 'Kpanvo Luna' (Chief drummer) of Kpanvo how he learned the trade, his response was: As early as two, I was given an immature drum where I learned how to drum. Then from about age ten, I and others gathered around the compound with our teacher every evening after supper. We were thought the appellations of Dagbon kings and we recited them, 
starting from our family, the overlord of Dagbon, extending it to other kings till we were able to commit them to memory. This went on for some time, while we followed others to social gatherings till I became a master of my own and was appointed "Luna" that is the chief drummer (Lunsi/interview/2013). Currently, he has a lot of drummers under him by virtue of his status as a chief drummer. He also works with the Centre for National Culture in Tamale. Even though he is illiterate, his boss at the Centre considers him as a professor in his own right. A baansi being considered as a professor by his boss means that he is learned and has a lot of knowledge and skills in doing his job. The above analysis shows that the baansi like academic librarians are knowledgeable. This means they can work together and learn from each other.

\section{Codification}

Like the baansi academic libraries also use codes to convey meaning. In the library systems, applying codes to library materials serve as the key to knowledge. This also applies to the baansi. The academic libraries, using the Library of Congress Classification Scheme as an example, use a mixture of English alphabets (upper case) and Arabic numerals as class numbers as code todivide the field of knowledge into twenty large classes. Every item in the library has a specific code with a call number that is unique to that item and this helps in arrangement and easy retrieval of the materials in the library. The baansi equally use codes. The drum language is basically a special beat played on the drum (including other instrument of communication in Dagbon) which is given a particular meaning. The dance, gestures, and drum beats are all codes employed by the baansi to communicate with their audience.For instance, Namogyilli mal kpiong pam, a beat on the drum means, Namongu is very powerful. The codes used by the baansi entail activities and processes for converting tacit data and information which is possessed by the elders as part of their oral tradition through meaning-making mechanisms that turn them into the knowledge which allows for the transfer into explicit form.

\section{Social growth}

Academic libraries, like the baansi, help promote the social wellbeing of the communities they serve. Social development according to Economic and Social Inclusion Corporation, ${ }^{16}$ is about improving the wellbeing of every individual in society so they can reach their full potential. The primary role of the academic library is to acquire, process, preserve, and disseminate recorded information. Academic libraries inform users and other members of the community they serve by presenting them with accurate information that guides their actions and help make good decisions that promote economic and social development. In like manner, baansi also provide useful information to their audience, chiefs and elders to make informed decisions. The baansi also preserve this information for future generations. Abdulsalami, Okezie and $\mathrm{Agbo}^{15}$ stipulate that, the availability and free flow of information bring about knowledge which has great potentials to provide impetus for the social, cultural, spiritual, political, economic, scientific and technological advancement of a nation as well as individual growth.

According to Abdulsalami et al. ${ }^{15}$ the library architecture acts as not only a surrounding framework, but also as a healthy "space" where ideas can flourish, live, grow and even be protected. This is evidenced in all the three libraries understudied for this analysis. All their books and other informational resources are ideas from people, some of which date back many centuries but still live on in the collections.
Even after the death of great authors their ideas still flourish in books and other information sources. Family members and also entire communities are often proud and share in the joy and satisfaction derived from their books. The baansi like the academic libraries preserve the deed and exploits of the chiefs of Dagbon. Even though some of these chiefs have passed away many years ago, the baansi through their performances make the chiefs live on in memories of many generations. These examples encourage other chiefs and people to attain certain standards worthy of emulation, thereby promoting social and economic development which enables them to contribute positive ways in the community.

Additionally, academic libraries like the baansi provide systems for the regeneration of knowledge. For instance, the three academic libraries understudied for this analysis provide space for students to study and interact. The spaces are enough for individuals and groups to work either independently or in groups and this helps to promote socialization among the users. According to Boakye ${ }^{17}$ this space enhances learning, provides an environment that is both academic and social for students and thereby fostering a sense of community on the university campus. Similarly, the baansi also provide space and systems for socialization. For instance, during Samban Luya, and other occasions such as the installation of chiefs and celebration of weddings, they create situations for socialization and exchange of knowledge among members of the baansi and the community at large. These systems present new expertise of knowledge and rejuvenation of the community and the individual.

\section{Synergies for co-evolution}

Both Western and Indigenous knowledge systems represent national resources. Indigenous knowledge frames can complement some of the mechanical and technical precision capabilities of the Western knowledge systems and generate forms of creativity that will benefit and empower everyone. ${ }^{18}$ According to Mazzocchi, ${ }^{19}$ by acknowledging the uniqueness of each knowledge system, we can go well beyond a mere pluralist approach to knowledge. The uniqueness of the baansi and academic libraries and their points of intersection are as shown in Figure 1, below which has already been discussed. The commonality between the two systems, living (baansi) and academic libraries provides a window possible for synergies between the two systems. Kawagley and Barnhardt ${ }^{20}$ posit that, there are ways to develop linkages that connect different worldviews. Banda ${ }^{21}$ add that, there are multiple linkages among indigenous knowledge, formal, informal and non-formal education systems. These linkages can form the basis for the mainstreaming of indigenous knowledge into the formal and non-formal curricula. The proposed model in Table 2 is a recommendation from the Divergences and the Convergence of the systems as discussed for possible synergy.

It is clear from the analysis that there is a great lacuna between the living libraries of indigenous peoples and the Western-modelled academic libraries, especially so in the case of Ghana. This is attributable to the fact that academic libraries in Africa specifically those in Ghana have not accepted IK as an authentic knowledge that can be utilized by people in academia. Academic libraries place themselves in an elite category by projecting themselves as the 'ivory towers' that serve only those in the academy. Due to this colonial, elite posturing, even in this era of multimedia communications, academic libraries have not been able to apply themselves to connecting effectively will IKS. As such they work to maintain rather than transcend the colonial borders/barriers. 
Table 2 Options of creating synergy between Baansi and Academic Libraries.

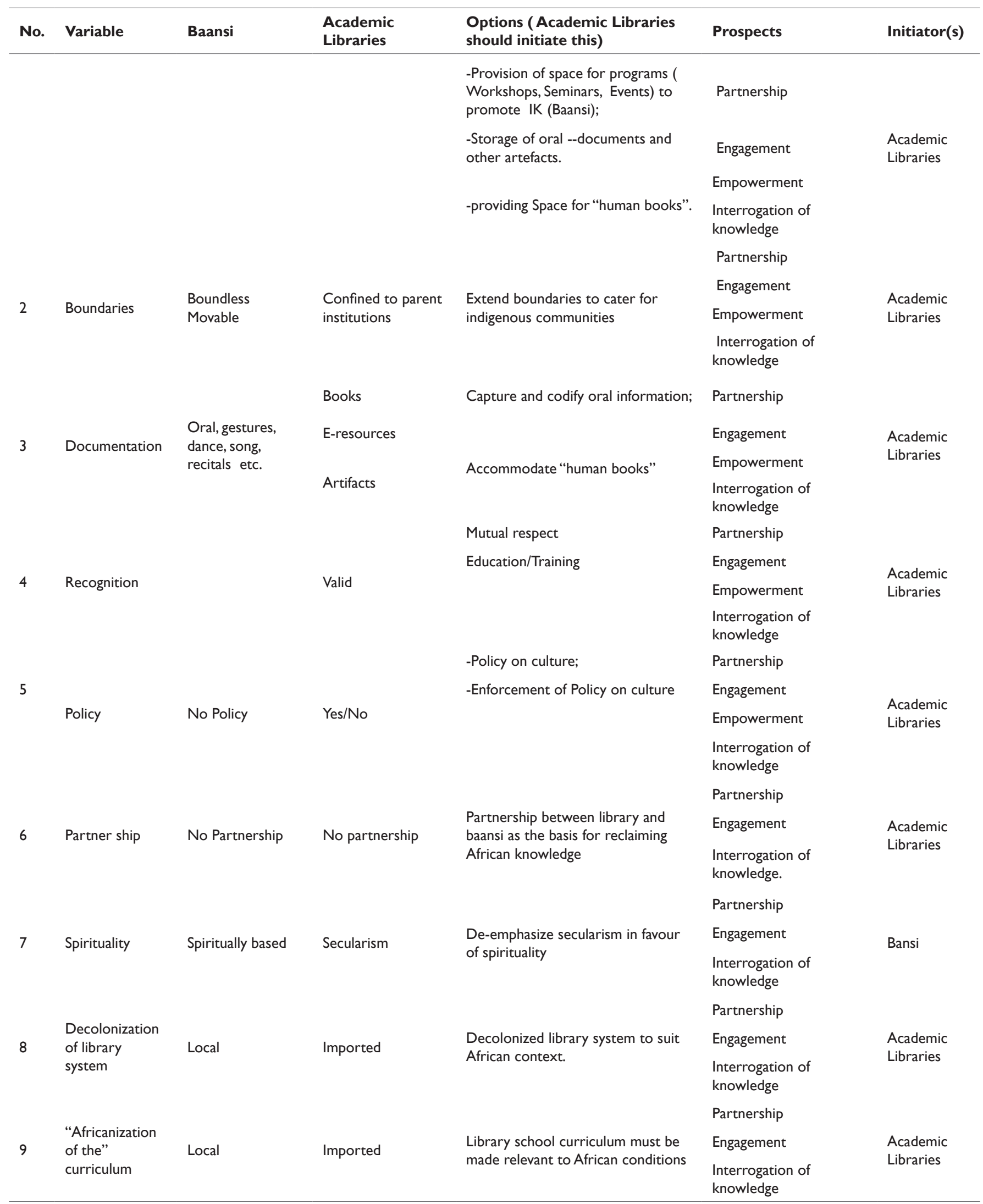




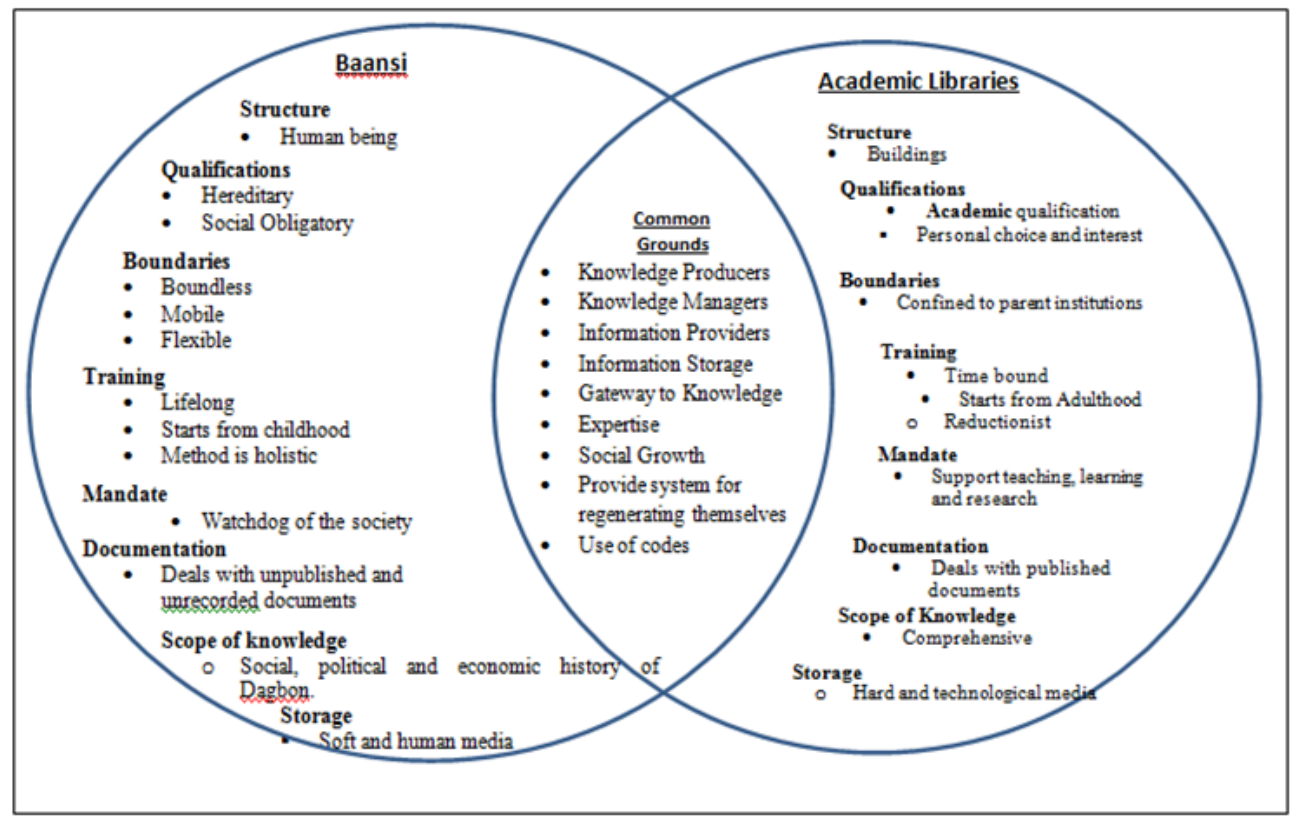

Figure I Difference and Similarities between Academic Library and Dagbon.

The researcher is of the view that $\mathrm{AL}$ can transcend their boundaries and reach out to the unlettered class. The services of the academic library can be designed in a way to accommodate both the lettered and the unlettered. This is a very tangible idea because, of the two systems, the AL has a better chance at ensuring a preservation of both books and culture. For indigenous communities of knowledge, traditionally multiple media platforms have been used to capture, transmit and conserve knowledge. However, these have not always been effective as they continue to face the threat of annihilation and extinction. For example, in a group discussion, members were of the opinion that: Formal education is taking over the baansi system; the young ones are not enthused about baansi; some do not care about the history of the ancestors; some educated people are also running away from the tradition. Furthermore, IK is faced with the further challenge of globalization and its antecedents, academic libraries who claim superior and professional status in knowledge management ought to be stepping out and taking up the challenge of recreating themselves to support such efforts to protect indigenous traditions.

\section{Explanation of the proposed model}

The model recognizes divergences and proposes a synergy for baansi and academic libraries as explained below:

\section{Provision of library space}

The entire library architecture acts as a healthy "space" where ideas can flourish, live, grow and even be protected. For successful synergy between the academic libraries and the baansi, there should be collaboration between academic librarians and indigenous knowledge communities (akarima, goojie and lunsi) as well as the larger society (elders, community leaders and/or government officials) to organize workshops, and meetings, where relevant information can be passed orally. Academic libraries can provide a space for indigenous programs/knowledge to be shared. Furthermore, academic libraries can provide space for documentation and storage of indigenous materials and recordings such as audio and video recordings and, artifacts.

\section{Providing access to living libraries (Baansi)}

Living libraries symbolize knowledge that is interactive rather than documented in print. Collaborating, cooperating and sharing of experiences help remove prejudice, promote unity and development. In recent times, the concept of human library has been introduced in many countries like Hungary, Norway, Iceland, Sweden, Finland, America, Asia and South Africa. According to Shannon and Bossaller the concept of human library is a way of stimulating and enlivening academic libraries. This can be adopted by the academic libraries in Ghana where programs that can connect students with Living Libraries (baansi) can be organized. In this way, students will understand and appreciate indigenous knowledge. The aim of a living library is to make it possible for the academic library and the baansi to coexist. The engagement of the baansi by the academic library is aimed at integration, where both of them respect each other's values. Integrating academic libraries and the baansi, storytelling, and personal interaction in the academic library is laudable since its will bring human experiences into the stacks.

\section{Documentation}

Oral communities are losing their 'living libraries' and if nothing is done to manage the knowledge the baansi possess it may be distorted or lost. The traditional historians of Dagbon are human memories of the deeds and exploits of kings as they are told and displayed to younger generations; hence, the archiving of such rich oral traditions such as those of Dagbon and such others nationwide cannot be over emphasized. The life span of these living libraries as we have now is short because sooner or later the entire generation will die. Additionally, the baansi deal with unrecorded and unpublished 
documents which exist in their minds. When the holders die, their knowledge dies with them, unless passed on to another. Learning from and using academic library's print and electronic media will help conserve indigenous knowledge for generations. Academic libraries can take advantage of the highly sophisticated systems of knowledge production, accumulation and dissemination of the Western system to the advantage of the indigenous system. Technologies like radio and television can also be an effective tool to provide relevant information to our rural communities.

\section{Training/recognition}

There are negative perceptions of IK even among the educated African elite and also many Africans who were converted to either Christianity or Islam. As a result, many Africans look down on their own cultural heritage. This has affected their worldviews and definitely the kind of knowledge we provide to support teaching and learning in our various universities in Ghana. For the successful coexistence between the baansi and academic libraries for joint learning and co-evolution of knowledge, academic libraries have to de-school and re-school themselves on the importance of African culture. Training of library professionals must not only be based on Western theories but also there is the need to integrate indigenous knowledge and Western knowledge so that library professionals can comprehend the complementary nature of the two as useful resources in tackling the problems of contemporary society. This will help to demystify the parable that professors are only found in universities because oral communities also are fertile grounds for professors.

\section{Enforcement of international/national/institutional policy on culture}

The International Federation of Library Associations and Institutions (IFLA) which is the parent body for Library Associations in the world has recognised IK and has made statements that urge all libraries in the world to recognise AIK and as such to collect, preserve, and make it available to the public. The Ghana National Policy on Culture states that schools, colleges and universities have a major role to play in ensuring that culture is taught at all levels of education. Also, among the key players in the promotion of our culture are libraries and archives. The policy provides that Libraries stock books, films, records and tapes, CD Rom, Compact disc and other multimedia materials on African arts and culture, and indigenous science and technology. The Policy also stresses the need to integrate culture studies into the educational curriculum.

\section{Partnership}

Hyun $^{22}$ posits that several authors have argued that the higher education curriculum clearly reveals a need to transform beyond the single/mono-disciplinary, transgressing disciplinary boundaries and leading toward transdisciplinary, borderless engagement. Academic libraries have to partner with the baansi to bridge that knowledge gap. This framework also takes into consideration that indigenous knowledge research takes a holistic approach by involving all the stakeholders in solving the perceived problems in order to integrate indigenous knowledge into the academic library system. We need to discover bridges, interconnectedness, and interdependence among different areas of knowledge (hard, social, and applied sciences). ${ }^{22}$

\section{Decolonization of library system}

Africans need to decolonize their library system to suit the Africa context. African scholars must promote their own "home grown indigenous perspectives steeped in culture-specific paradigms" in the Western academy. ${ }^{23}$ In other words, libraries are not only blocks and mortar edifies but indigenous community have their own libraries. Libraries are defined as "repositories of knowledge", and the baansi of Dagbon is the living libraries of the indigenous knowledge community, are not left out because they have a vast pool of knowledge to be tapped. As living libraries, the only difference is that, books in the living libraries are people. The Living Library concept seeks to challenge prejudice and discrimination. Living libraries comprised of living books representing a range of backgrounds who might give themselves 'book titles'. After reading, they return the book to the library and, if they want, borrow another. Examples of this concept as stated in Lismore, on the far - north coast of New South Wales, Australia in November 2006, Malmö library, Sweden and Halifax library model. This model makes a strong case for possible adoption in the case of academic libraries in Ghana. This will demystify current concept of librarianship for libraries to be seen as sites of conscience and decolonization because knowledge produced will not only be Eurocentric but also include indigenous traditions.

\section{Africanization of the library school curriculum}

Proper curriculum planning by African library schools and breaking away from irrelevant training are crucial..$^{24}$ Library school curriculum should be related to African situations and open to changes in library services. That is the curriculum should be guided by African cultural traditions which are based on oral traditions and artefacts.

\section{Conclusion}

The paper explored possible ways to integrate the knowledge management mechanisms of indigenous knowledge communities with special reference to court musicians known as the baansi as living libraries and institutional libraries as academic library with the view to enhance the responsiveness and benefits of Ghanaian library services. The study also sought to provide a platform for the indigenous knowledge community of Dagbon to tell their own stories in their own ways. This is in line with Smith, ${ }^{25}$ who posits that it is not about indigenous people giving an oral account or a genealogical naming of land and the events but to give testimony to and restore their spirit and revitalize a worl.d that is fragmented and dying. Most importantly, this study provides valuable recommendation to librarians to seek ways to provide access to both indigenous knowledge and Western knowledge in order to benefit from both the lettered and unlettered in their efforts to produce and share knowledge. ${ }^{25-30}$ Furthermore, this study aimed to identify and recommend appropriate areas of collaboration between the living libraries of Dagbon and academic libraries of Ghanaian universities with the view to promote inter-science dialogue that could lead to mutually sustaining local and regional exchanges for sustainable development. ${ }^{31-42}$ And as it has been proposed in Table 2, Academic Libraries should lead the way by extending their hand to their colleagues from the other side for possible dialogue. ${ }^{43-51}$

\section{Acknowledgements}

None. 


\section{Conflict of interest}

Author declares that there is no conflict of interest.

\section{References}

1. Salifu A. Names that prick: Royal praise names in Dagbon, northern Ghana. Indiana University; 2008

2. Oppong C. Growing up in Dagbon. Legon: Institute of Adult Education; 1971.

3. Chista CT, Abdullahi T. The challenges and opportunities of preparing LIS students for orally based communities. Paper presented at World library and information congress, 76th IFLA general conference and assembly, Sweden: Gothenburg; 2010.

4. Collings P. Participant observation and phased assertion as research strategies in the Canadian Arctic. Field Methods. 2009;21(2):133-153.

5. Agar M. The Professional Stranger. An Informal Introduction to Ethnography. Academic Press, Orlando. 1980.

6. Kirk J, Miller ML. Reliability and validity in qualitative research. Beverly Hills, CA: Sage; 1986.

7. Nyamnjoh FB. A relevant education for African developmentSome epistemological considerations. Africa Development-Senegal. 2004;29(1):161-184

8. Heng LK. Impact on learners' uncertainty reduction with the infusion of information literacy skills training in problem-based learning environment. Academic Research International. 2013;4(6):249.

9. Lor P. Storehouses of knowledge? The role of libraries in preserving and promoting indigenous knowledge. Indilinga African Journal of Indigenous Knowledge Systems. 2004;3(1):45-56.

10. Moahi K. Providing library services in the digital era: Opportunities and threats for libraries in Africa. Paper presented at the World Library and Information Congress: 69th IFLA General Conference and Council; 2003.

11. Gibbons M, Limoges $\mathrm{C}$, Nowotny $\mathrm{H}$, et al. The new production of knowledge: The dynamics of science and research in contemporary societies. London: Sage; 1994.

12. Atkinson R. Transversality and the Role of the Library as Fair Witness1. The Library. 75(2):2005.

13. Bunting I, Cloete N. Cross-national performance indicators: A case study of eight African universities. Cape Town: CHET; 2012.

14. White T. Knowledge management in an academic library: based on the case study KM within OULS. Paper presented at the World Library and Information Congress: 70th IFLA General Conference and Council; 2004.

15. Abdulsalami L, Okezie Q, Agbo A. The role of the library in the promotion of knowledge societies in Nigeria. Advances in Applied Science Research. 2013;4(1):58-70.

16. Economic and Social Inclusion Corporation. What is social development? The New Brunswick Economic and Social Inclusion Plan. Canada: New Brunswickers; 2009.

17. Boakye G. New kid on the block: the research commons. In: Thompson ES, Kofi CY, editors. Proceedings of the 7th Seminar of the Committee of University Librarians and their Deputies. Academicand Research Libraries in Transition. Tamale: CULD; 2010.

18. Odora Hoppers C. Indigenous knowledge and the integration of knowledge systems: Towards a conceptual and methodological framework. Indigenous knowledge and the integration of knowledge systems: Towards a philosophy of articulation. 2002. p. 2-22.
19. Mazzocchi F. Western science and traditional knowledge. EMBO reports. 2006;7(5):463-466.

20. Kawagley AO, Barnhardt R. Education indigenous to place: Western science meets Native reality. In: Smith GA, Williams DR, editors. Ecological education in action: On weaving education, culture, and the environment. Albany, NY: State University of New York Press; 1999. p. $117-140$.

21. Banda D. Education for all (EFA) and the African indigenous knowledge systems (AIKs): the case of the Chewa people of Zambia. Nottingham: University of Nottingham; 2008.

22. Hyun E. Transdisciplinary higher education curriculum: a complicated cultural artifact. Research in Higher Education Journal. 2011;11:1.

23. Dei GS. Indigenous anti-colonial knowledge as 'heritage knowledge'for promoting Black/African education in diasporic contexts. Decolonization: Indigeneity, Education \& Society. 2012;1(1).

24. Mostert BJ. African public library systems: A literature survey. Library and Information Science Research. 2001;11(1).

25. Smith GH. Indigenous struggle for the transformation of education and schooling. Transforming Institutions: Reclaiming Education and Schooling for Indigenous Peoples. 2003;1-14.

26. Abah J, Mashebe P, Denuga D. Prospect of Integrating African Indigenous Knowledge Systems into the Teaching of Sciences in Africa. American Journal of Educational Research. 2015;3(6):668-673.

27. Agrawal A. Indigenous and scientific knowledge: some critical comments. Development and change. 1995;26(3):413-439.

28. Alemna AA. Oral literature in African libraries: implications for Ghana. Indiana: African Studies Program, Indiana University. 1993.

29. Amadi AO. African libraries: Western tradition and colonial brainwashing. Metuchen NJ: Scarecrow Press; 1981.

30. Brawer W. LibraRRRy: Center for Reuse, Regeneration and Resiliency. 2014.

31. Chernoff JM. African rhythm and African sensibility: Aesthetics and social action in African musical idioms Vol 36. Chicago : University of Chicago Press; 1979.

32. Cragan JF, Kasch CR, Wright DW. Communication in Small Groups: Theory, Process, Skills. Boston: Wadsworth Cengage Learning; 2009.

33. Haverkort B, Apusigah A, Millar D, et al. Learning Together Developing Inclusive Knowledges and Sciences. Vol 1: Concepts and Challenges in Endogenous Development, Education and Research. Ghana: Tamale; 2012 .

34. Hildreth PM, Wright $\mathrm{P}$, Kimble C. Knowledge management: are we missing something? In: Brooks L, Kimble C, editors. Paper presented at the Proceedings of 4th UKAIS Conference, University of York, McGraw Hill; 1999.

35. Letsekha T. Revisiting the debate on the Africanisation of higher education: An appeal for a conceptual shift. The Independent Journal of Teaching and Learning. 2013;8:5-18.

36. Mabawonku I. The systematic management of indigenous knowledge: a review of oral information projects in a library school. Proceedings of the SCECSAL. 2002.

37. Madhu P. Towards a Praxis Model of Social Work: A Reflexive Account of 'Praxis Intervention'with the Adivasis of Attappady. PhD Dissertation, Kottayam: Mahatma Gandhi University; 2005.

38. Mbembe A. The thing and its double in Cameroonian cartoons. Readings in African popular culture. 1997;151-163. 
39. Meyer HW. The Nature of Information, and the Effective Use of Information in Rural Development. Information Research: An International Electronic Journal. 2005;10(2):2.

40. Miller R. A brief introduction to holistic education the encyclopedia of informal education. 2000 .

41. Nyana SA. Creating a library system that serves the needs of rura communities in Africa South of the Sahara. Journal of Pan African Studies. 2009;3(1):9-23.

42. Nakata M, Langton M. Australian indigenous knowledge and libraries. 2005 .

43. Ngulube P. Managing and preserving indigenous knowledge in the knowledge management era: challenges and opportunities for information professionals. Information Development. 2002;18(2):95-102.

44. Østreng W. Reductionism versus Holism-Contrasting Approaches. Consilience. Interdisciplinary Communications. 2005;11-14.

45. Plockey FDD. Enhancing the Reading Culture in Ghana: Key Strategies to National Development. Ghana Library Journal. 2012;24(22):32-46.
46. Rouse J. Global dissemination of indigenous knowledge: Contradiction the way forward. Washington DC: World Bank; 1999.

47. Sen B. Indigenous knowledge for development: Bringing research and practice together. The International Information \& Library Review. 2005;37(4):375-382.

48. Sharma C. Use and impact of e-resources at Guru Gobind Singh Indraprastha University (India): A case study. Electronic Journal of Academic and Special Librarianship. 2009;10(1):1-8.

49. Trivedi M. Knowledge management in health science libraries. Electronic Journal of Academic and Special Librarianship. 2007;8(2).

50. Woytek R, Mehta SP, Mohan PC. Indigenous Knowledge: Local Pathways to Global Development. Washington, DC: The Knowledge and Learning Group; 2004.

51. Woodley E. Local and Indigenous Ecological Knowledge as an Emergent Property of a Complex System: A Case Study in the Solomon Islands. Paper prepared for the Millenium Ecosystem Assessment Conference Bridging Scales and Epistemologies. 2004. p. 17-20. 